\section{Southwest Florida Research and Education Center: Agricultural Research and Education for 1996 and Beyond}

As the population of the world grows and the percentage of land used for agriculture decreases, new technologies and advances in horticulture and agronomy become paramount. The Southwest Florida Research and Education Center (SWFREC) faculty is continually conducting research in these two disciplines and passing on their results in the form of the latest advances in technology and knowledge to producers and other clientele. These advances will allow Florida agriculture to remain strong and competitive in world markets while maintaining and enhancing the natural resources of the area.

SWFREC is a part of the Univ. of Florida's Institute of Food and Agricultural Sciences (IFAS). The center was established slightly north of Immokalee in 1955 and initially was the South Florida Field Laboratory. SWFREC facilities are located on a 130-ha tract of land and includes $1600 \mathrm{~m}^{2}$ of administrative and laboratory space, research greenhouses, and maintenance facilities. Currently, 12 ha are used for vegetable research, 28 ha for citrus, and 47 ha for range programs, including a 6 -ha scrub jay (Aphelocoma coerulescens) preserve and a 12-ha water reservoir (Fig. 1).

\section{HISTORY}

Research at the center initially examined the principal crops of the area: watermelons [Citrullus lanatus(Thunb.) Matsum. \& Nakai], tomatoes (Lycopersicon esculentum Mill.), cucumbers (Cucumis sativus L.), sweet peppers (Capsicum annuum L.), and summer squash (Cucurbita pepo L.). Variety tests of improved and native forage crops also were conducted. In the early 1980 s, the rapidly expanding citrus industry in southwestern Florida caused the center to focus on this additional commodity, and by 1988 , a fully developed research and extension program in citrus was added. Today, research at the facility has grown to encompass other disciplines, such as entomology, plant pathology, range science, and soil and water research.

Received for publication 2 Oct. 1995. Accepted for publication 10 Dec. 1995. The cost of publishing this paper was defrayed in part by the payment of page charges. Under postal regulations, this paper therefore must be hereby marked advertisement solely to indicate this fact.

${ }^{1}$ Former Center Director. Currently, Center Director, Indian River Research and Education Center 2199 South Rock Road, Fort Pierce, FL 34945.

${ }^{2}$ Former Communications and Media Coordinator.

Front cover: A Florida citrus blossom. Photo by Bob Rouse, citrus horticulturist, Univ. of Florida, SWFREC, Immokalee.
All of these programs strive to:

-Expand and develop new knowledge and technology as it relates to vegetable, citrus, beef, and sugar cane production to allow Florida agriculture to remain efficient and economically competitive with other agricultural areas of the world.

-Assist the County Cooperative Extension Service offices, Univ. of Florida/ IFAS campus departments, and other research and education centers in extension, education, training, and cooperative research programs for the benefit of
Fig. 1. SWFREC administrative office building.
Florida producers, students, and consumers.

- Continually adapt research to meet the changing needs of Florida agriculture while maintaining and enhancing the natural resources of Florida. Today more than $60 \%$ of the center's research and extension efforts have a strong agroecology emphasis and are directed at maintaining and enhancing the natural resources of the region we serve, especially water quality, water conservation, and wildlife.

\section{HORTICULTURAL RESEARCH AND EXTENSION PROGRAMS}

\section{Citrus}

The citrus program meets the applied research and extension needs for 72,000 ha of commercial plantings in the southwestern Florida Gulf Coast region. The latest research
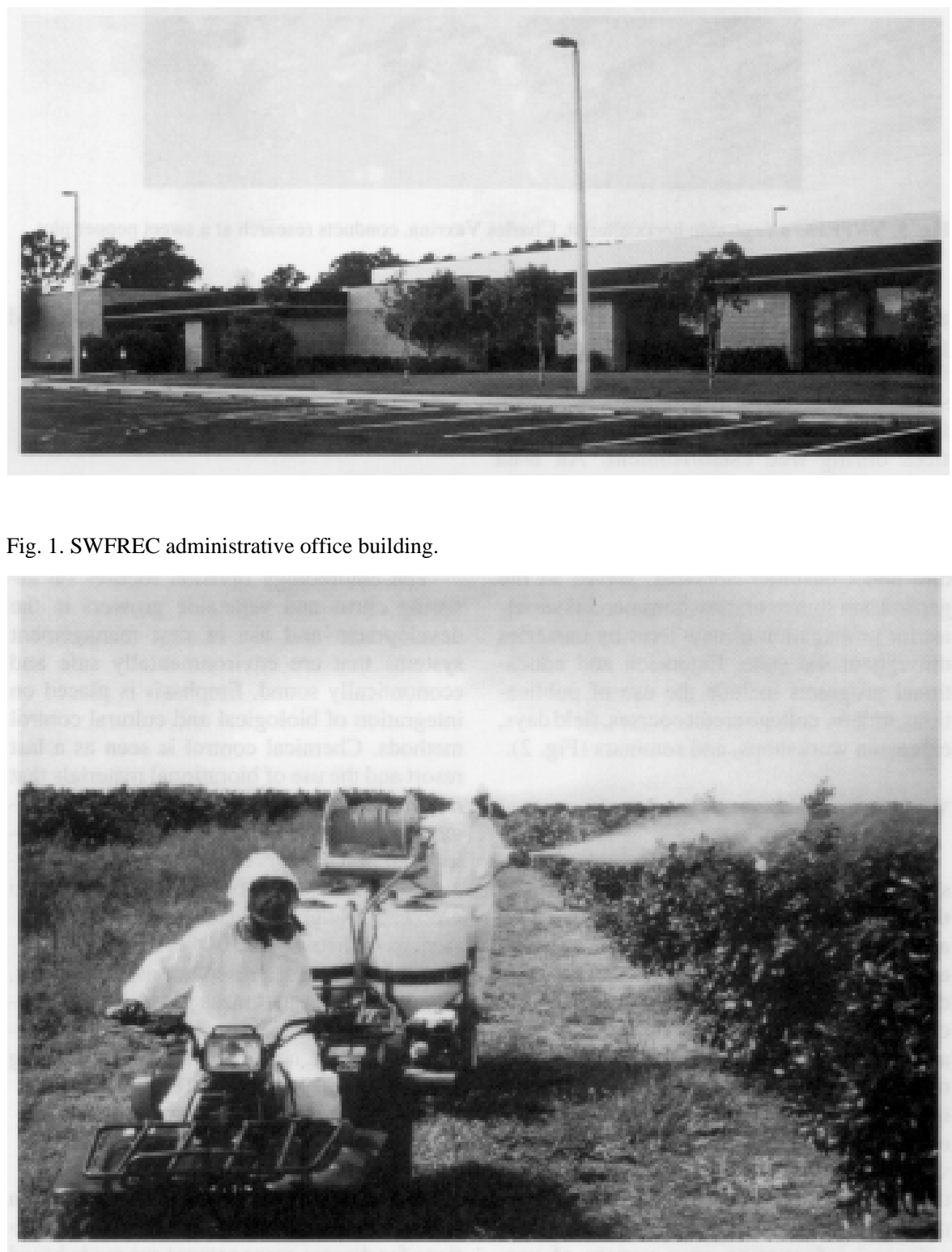

Fig. 2. Assistant at SWFREC sprays citrus trees for citrus leafminer. 


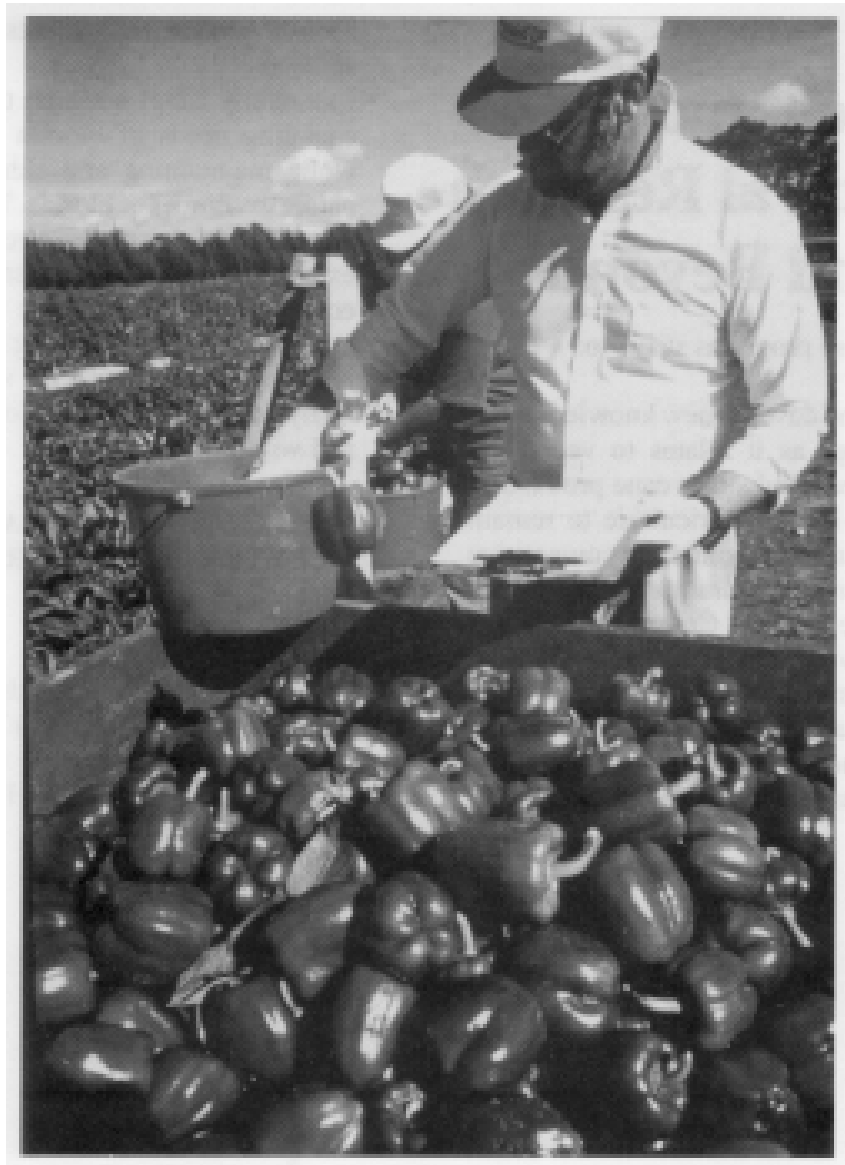

Fig. 3. SWFREC's vegetable horticulturist, Charles Vavrina, conducts research at a sweet pepper plot.

and technology is provided in nursery tree production, controlled-release nutrition sources for establishing young trees, environmentally sound cover crops for row middles in bedded flatwoods groves, and general cultural practices during tree establishment. An 8-ha budwood foundation planting, maintained in cooperation with the Florida Dept. of Agriculture and Consumer Services, serves as the germplasm source of most commercial varieties for propagation of new trees by nurseries throughout the state. Extension and educational programs include the use of publications, videos, college credit courses, field days, extension workshops, and seminars (Fig. 2).

\section{Vegetables}

This program provides statewide leadership in research and extension, specifically in the areas of vegetable transplant production and stand establishment. The research and extension programs focus on practices that are designed to reduce early crop losses due to climate, soil conditions, pests, and diseases, and to increase cropping efficiencies. In addition, the overall program is part of a preexisting statewide program dealing with a broad range of production practices for numerous vegetable crops. The objectives are to impart up-to-date knowledge, develop and implement improved techniques, and transfer technological information on a variety of vegetable cultural practices. These goals are met through the use of extension publications and programs, field days, and seminars (Fig. 3).

\section{HORTICULTURE SUPPORT DISCIPLINES}

\section{Entomology}

The entomology division focuses on assisting citrus and vegetable growers in the development and use of pest management systems that are environmentally safe and economically sound. Emphasis is placed on integration of biological and cultural control methods. Chemical control is seen as a last resort and the use of biorational materials that minimize negative impacts on beneficial organisms is encouraged. Techniques are established based on tests conducted in the laboratory, greenhouse, and field, then transferred to growers through extension agents and extension specialists as part of field days, demonstration plots, oral presentations, fact sheets, popular articles, and mass media. Also available are short courses on citrus pest management and a diagnostic service for identifying insect and mite specimens (Fig. 4).

\section{Plant pathology}

The most visible function of this program is the Plant Diagnostic Clinic. Recommendations for disease management are made based on clinic results. SWFREC is actively in- volved in developing and implementing a statewide network, called Pest Alert, to exchange information within the Univ. of Florida on the appearance of new pests and serious outbreaks of previously recognized pests. Ongoing research and extension efforts focus on identifying alternative plant disease hosts for vegetable viruses, adopting integrated control strategies of soilborne diseases of vegetables and ornamentals, and evaluating fungicides for controlling foliar diseases of citrus and vegetables. In addition, extension workshops and presentations are conducted on plant disease identification and integrated pest management.

\section{Soil science}

Soil scientists are involved in research and extension activities in soil fertility and water management, with the objective of increasing nutrient use efficiency while minimizing the impact on the environment. Research areas include rate and frequency of nutrient application, evaluation of fertilizer sources, applications of nonhazardous organic wastes, microirrigation management, and use of plant tissue testing for diagnostic purposes. The extension component emphasizes educational programs that deal with the usefulness and limitations of soil and plant tissue testing, interactions of fertilizers and organic wastes with the soil, management practices to increase fertilizer use efficiency, nutritional problems encountered in alkaline soils, pesticide $\times$ soil interactions, and nutrient and pesticide movement in soil.

\section{Water quality}

The goal of this research and extension programs is to help forge a long-term sustainable balance between the agricultural production sector and the unique ecosystem. Water resource issues, quality and quantity, are crucial to the health of our environment and are vital for the prosperity of agriculture and its associated way of life. The water quality laboratory conducts research related to the movement of fertilizers, pesticides, and herbicides in the aquatic environment, including surface and ground water. Laboratory results are combined with sophisticated computer models to help researchers develop strategies to better manage our rural land and water resources.

\section{Water management}

The research and extension efforts of this program focus on soil-plant-water relationships and identification of the most efficient methods for water and nutrient management on high water-table sandy soils while maintaining the water quality and natural resources of the area. Researchers evaluate existing irrigation and drainage systems and make recommendations for providing adequate water to area crops while conserving water and energy. Tours, workshops, and assisting growers in designing water management systems comprise extension and educational efforts. 


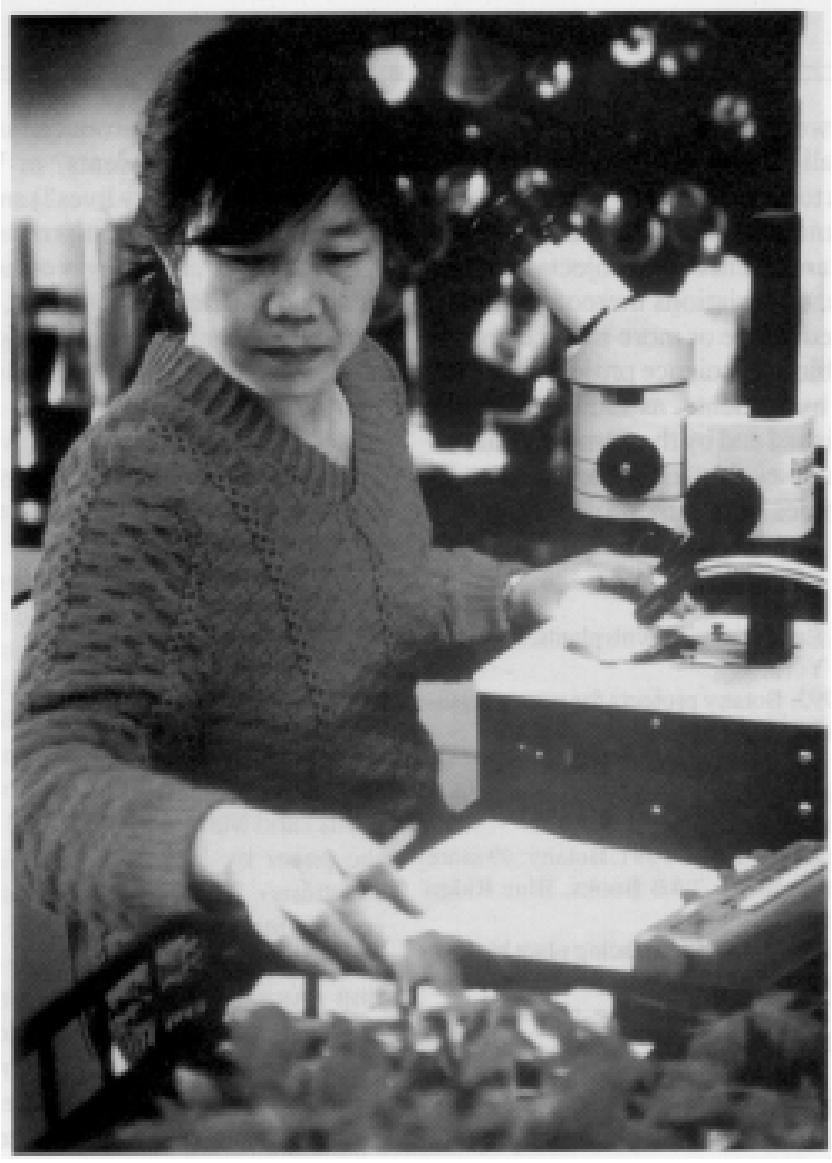

Fig. 4. Yong Mei Zhang, technical assistant in the Entomology Dept., conducts laboratory research.

\section{CLASSROOM EDUCATION}

In addition to research and extension, SWFREC's other primary focus is classroom education. Through a cooperative effort with Edison Community College (ECC), SWFREC faculty teach courses that lead to an associate of science degree in citrus production technology from ECC. Faculty from SWFREC teach six Univ. of Florida lower-division citrus production technology courses at the Immokalee location and ECC offers the general and supporting courses for the degree program. The six citrus production courses include citrus culture I and II; pests and pesticides; current topics in agriculture; soils and fertilization; and irrigation and drainage. The program has been in existence for 4 years and more than 20 students have graduated from the program; more than 50 additional students are at various stages in the program.

A newly designed educational program is being developed between SWFREC and the main Univ. of Florida campus in Gainesville. This new program involves down-linking via satellite various agriculture courses that are being taught on the Gainesville campus to the Immokalee location. The courses offered via satellite are junior/senior level courses and allow area students the opportunity to continue their education without the necessity of moving to Gainesville or commuting to the main campus.

Soon a new educational opportunity will be offered to area residents. In Fall 1997, southwestern Florida will become the home of Florida Gulf Coast Univ. (FGCU)_Florida's newest university and its tenth. SWFREC will coordinate two bachelor of science degree programs in cooperation with FGCU. It is anticipated that eight faculty housed at the FGCU campus will be Univ. of Florida faculty. These eight faculty members will be administered by the SWFREC director and will teach major classes in the horticulture science and agribusiness degree programs. Students will take general education courses and elective courses from either FGCU or $\mathrm{ECC}$ and take major classes from the Univ. of Florida faculty. These two majors will carry Univ. of Florida degrees even though they are being taught at the FGCU site.
In conjunction with numerous classroom programs now available at SWFREC, Bob Rouse was recently appointed to serve as the first undergraduate teaching coordinator at SWFREC. Rouse will work closely with ECC, FGCU, and the Gainesville campus to ensure that the classroom education offered at SWFREC meets the needs of the educational institutions and the students.

\section{FACULTY}

To offer the quality research, extension, and educational programs at SWFREC, a highly professional and talented faculty is in place. Currently, SWFREC has nine faculty members: Robert Rouse, citrus horticulturist; Charles Vavrina, vegetable horticulturist; Robert McGovern, plant pathologist; Thomas Obreza, soil scientist; Philip Stansly, entomologist; Jeffrey Mullahey, range scientist; John Capece, water quality scientist; Rosa Muchovej, agronomist; and Donald Pitts, water management engineer. All faculty members report to SWFREC's center director.

Future plans at SWFREC include adding an agricultural economist to the staff. The economist will focus on producing and marketing major commodities of the area: citrus, vegetables, beef cattle, and sugarcane. Additionally, the effects of these commodities on the local environment and natural resource will be emphasized.

\section{THE FUTURE}

Agriculture in southwestern Florida is facing a new era. With a shifting emphasis to protecting and enhancing natural resources and increased government regulations, farmers need to find new ways of managing their operations to meet the regulations and protect our fragile environment. SWFREC will play a paramount role in these changing times by providing farmers the latest in research and technology to assist them in designing management practices that will comply with government regulations, protect the environment, and allow them to remain profitable and competitive in the global economy. In addition, SWFREC will be responsible for extension efforts that will educate the general population on the importance of agriculture not only in southwestern Florida but across the United States and the world.

Calvin E. Arnold ${ }^{1}$ and Christine Osterlund ${ }^{2}$ Southwest Florida Research and Education Center P.O. Box 5127

Immokalee, FL 33934 